\title{
ALKUSZI MINŐSÉG BIZTOSÍTVA
}

Turcziné Pálos Anna fótitkár, FBAMSZ (fbamsz@mail.datanet.hu),Dr. Exner Veronika biztosításiszakjogász, FBAMSZ (veronika.exner@niqual.hu)

\section{ÖSSZEFOGLALÓ}

Jelenleg egyetlen független biztosításközvetítői intézmény működik a hazai piacon, a biztosítási alkusz, amelynek funkciója, hogy az ügyfél megbízásából és érdekében eljárva nyújtson szakmai támogatást biztosítási területen. Az egyre terjedelmesebb és szigorúbb európai és magyar jogalkotási és jogalkalmazási gyakorlat azt kívánja biztosítani, hogy e szakma művelői az intézmény törvényi célját maradéktalanul megvalósítsák független, pártatlan és minőségi szolgáltatás nyújtása, a magatartási normák betartása, a tisztességes üzletmenet, a transzparencia biztosítása, az összeférhetetlenség kiküszöbölése révén. Ennek során a biztosítási alkusz cégek kötelesek az ügyfelek érdekeit védő szabályozásnak megfelelni, a biztosítási területet érintő jogszabályváltozásokat követni és betartani, a felügyeleti követelményeknek eleget tenni, a biztosítótársaságokkal együttműködni és szakmai ismereteiket folyamatosan naprakészen tartani. E szerteágazó követelményrendszerben való eligazodást, a minőségi alkuszi munkát segíti a Független Biztosítási Alkuszok Magyarországi Szövetsége.

\section{SUMMARY}

Currently the insurance broker is the only type of independent insurance intermediary operating on the domestic market, the function of which is to provide professional insurance support acting for and on behalf and in the interest of its clients. The increasingly extensive and stringent European and Hungarian legislation and application aims at having this profession achieve the purpose of its legal institution by providing quality service in an independent and impartial manner, complying with the standards of conduct, guaranteeing fair business and transparency and preventing conflicts of interest. In doing so, insurance brokers shall comply with any and all regulations on client protection, follow and comply with the changes of legislation concerning insurance, work in accordance with the regulatory and supervisory requirements, cooperate with the insurance undertakings and keep their professional knowledge up to date. The Association of Independent Insurance Brokers in Hungary helps to navigate in this diverse system of requirements and provide quality brokering service.

\section{Kulcsszavak: független biztosításközvetítő, etikai kódex}

Key words: independent insurance mediator, Code of Ethics

JEL: G22,

DOI: 10.18530/BK.2016.2.80

http://dx.doi.org/1018530/BK.2016.2.80

A biztositási tevékenységről szóló 2014. évi LXXXVIII. törvény, azaz az új Bit. hatálybalépésével egyetlen független biztosításközvetítői intézmény maradt a magyar biztosítási piacon: a biztosítási alkusz. Érdemes ezt a jogszabályváltozást megragadni, és körbejárni, hogyan működik egy minőségi szolgáltatást nyújtó, független biztositási bróker ma a magyar piacon, kinek és milyen követelményeknek kell megfelelnie, milyen területeken kell jártasságot szereznie. Kérdés továbbá az is, hogy milyen formában kaphat ehhez segítséget, hiszen látni fogjuk, hogy rendkívül széles körü és szigorú követelményrendszernek kell megfelelnie.

\section{| Hogyan müködik egy független biztosítási bróker?}

2011-ben a FBAMSZ közgyűlése beemelte logójába „A minőség biztosítva” szlogent, ezzel egyidejüleg pedig elfogadta és az alapszabály részévé tette az Üzleti Etikai Kódexet. A piacon egyedülálló kezdeményezéssel azt kívánta nyomatékosítani a tagság és a vezetőség, hogy a fogyasztók és a szakma számára is egyaránt fontos a biztosításközvetítői piacon meghatározni a „best practice”-t. A IMD hosszú évek óta zajló revíziójával párhuzamosan olyan, a saját korukat megelőző szabályokat rögzített a kódex, melyek csak később kerültek hivatalos szabályozásra, vagy éppen az idén februárban kihirdetett IDD implementálása során fognak - remélhetőleg - jogszabályokban megjelenni.

Összefoglalónknak nem célja, hogy részletezze, milyen kihívásokkal szembesül tevékenységi körtől függetlenül - egy cég vezetése, hiszen a jogszabályoknak megfelelő, profitorientált működés számos területen feltételez jártasságot, illetve követeli meg, hogy szakértőket vonjunk be a mindennapi munkába. Csak a legáltalánosabb körben gondolhatunk itt a cégjogra, adózásra és számvitelre, értékesítésre, marketingre, pénzügyi tervezésre, piacismeretre, humánerőforrás-kezelésre, munkajogra, amely sort még sokáig lehetne folytatni. Foglalkozni kívánunk viszont azzal, hogy ezen túlmenően, a szektorra jellemző szabályozásnak, illetve az alkusz funkciójának köszönhetően a figyelmet milyen további speciális területekre kell koncentrálni. 


\section{Az alkusz köteles megfelelni az ügyfélnek}

Az alkusz elsődlegesen az ügyfelének köteles megfelelni. Az alkusz az ügyfél megbízásából és érdekében jár el, a szakma elsődleges funkciója és létjogosultsága pedig éppen abban rejlik, hogy olyan pénzügyi területen nyúitson professzionális segítséget, amelynek mélyreható ismerete nem várható el az ügyféltől. Feladata a testre szabott tanácsadás, az ügyfél kockázatkezelésében való aktív részvétel és az ezzel kapcsolatos szakmai feladatok átvállalása.

Az Európai Unió biztosítási szektort érintő jogalkotása, fókuszában a fogyasztóvédelemmel, az utóbbi években folyamatosan arra törekszik, hogy egyre részletesebb és terjedelmesebb szabályozás révén biztosítsa Európa-szerte a tisztességes és megbízható üzletmenetet a biztosítások értékesítésének területén, az ügyfeleket és érdekeiket helyezve a középpontba.

A Független Biztosítási Alkuszok Magyarországi Szövetségének is elsődleges célja olyan alkuszok tömörítése, akik ezeknek a törekvéseknek ugyanúgy megfelelnek, mint a hazai és külföldi jogi szabályozás keretében, hatósági felügyelet során és bírósági gyakorlat révén meghatározott és kialakított szigorú magatartási és szakmai normáknak. Ennek érdekében már 2011-ben rögzítette minden tagjára nézve kötelező Üzleti Etikai Kódexét, amelynek alkalmazását, normáinak követését azonban tagsági körén kívül is ajánlja. Ez a dokumentum felöleli a szakszerü alkuszi tevékenységnek, az ügyfélkapcsolatok kezelésének, a függetlenség és érdekellentétek kezelésének, a díjazásnak és transzparenciának, valamint a tisztességes piaci versenynek az alapelveit.

\section{Tilos az ügyfelet megtéveszteni.}

Bár működési alapelvekről beszélünk, azok mégsem elrugaszkodott, általánosító szabályok, hanem a mindennapi gyakorlat során követendő előírások, kiemelve olyan részleteket is, ahol máig tetten érhetők hiányosságok a piacon: ilyen például az ügyfél biztatása a biztosítási szerződésnek a díj nem fizetésével történő megszüntetésére, annak következményeiről történő tájékoztatás nélkül.

Egyes pontjai jól összecsengenek a 2016 februárjában hatályba lépett és jelenleg implementációs szakaszban lévő, a biztosítási értékesítésről szóló 2016/97/EU irányelv (azaz IDD) egyes sarkalatos pontjaival. Ilyenre példa az az európai törekvés, hogy kapjon különös hangsúlyt az előzetes piacelemzés, a szükségletek és igények vizsgálata, a megfelelő réspiacra történő értékesítés és ennek utánkövetése. Ezzel összhangban rögzíti az etikai kódex, hogy az alkusz köteles az objektív biztosításszakmai szempontok mentén lefolytatott piacelemzés alapján javaslatot tenni az ügyfél feltárt igényei, szükségletei és kockázati viszonyai alapján a legalkalmasabbnak ítélt biztosítói ajánlat kiválasztására. Továbbá tilos az ügyfelet (ideértve a leendő ügyfelet is) megtéveszteni, ebbe beleértendő különösen az egyes elemeket kiragadó - főképpen a biztosítási díj vagy az alkuszi díjazás mértékét hangsúlyozó - hamis összehasonlítás.

Különös hangsúlyt fektet az irányelv az ügyfelek megfelelő tájékoztatására, kiemelve a díjazással összefüggő tájékoztatást és az összeférhetetlenség megelőzését. Ezzel kapcso- latban a FBAMSZ etikai kódexe a következőket rögzíti

- $\quad$ az alkuszi függetlenséggel összeegyeztethetetlennek tartja a biztosítótársaságokkal létesített minden olyan, az ügyfél előtt fel nem tárt kapcsolatot (nevezetesen közvetett vagy közvetlen részesedési viszonyt, megállapodást, elszámolási módszert, illetve

- konkrét jogcímétől függetlenül minden olyan pénzbeli vagy természetbeni előnyt, szolgáltatást, juttatást és ellentételezést), mely alkalmas arra, hogy érdekellentétet teremtsen az alkuszcég és ügyfele között, és végső soron befolyásolhatja az alkuszcégnek a biztosítók közötti választással kapcsolatos tanácsát.

Erösíti a díjazásról szóló tájékoztatásra vonatkozó szabály azt is, hogy az alkuszcég az ügyfél erre irányuló kifejezett kérésére köteles tájékoztatást adni az ügyfél által fizetett vagy fizetendő biztosítási díjba épített jutalék mértékéről, valamint konkrét jogcímétől függetlenül minden egyéb olyan pénzbeli vagy természetbeni előnyről, szolgáltatásról, juttatásról és ellentételezésről, amelyben az alkuszcég az ügyfél kockázatait elvállaló biztosítótól és/vagy annak viszontbiztosítójától, illetve harmadik személytől az ügyfél biztosítási kockázatainak az elhelyezésével kapcsolatban részesül.

\section{Azalkusz köteles megfelelni a biztosítási területet érintő, mindenkor hatályos jogszabályoknak}

Az alkuszoknak nemcsak az ügyfelekkel szemben általánosan elvárható, a FBAMSZáltal alapelv szintjén is megfogalmazott magatartási szabályoknak kell megfelelniük, hanem természetesen minden jogi normának, amely a biztosítási területen az alkuszok eljárását szabályozza. Az elmúlt években gyors egymásutánban jelentek meg az ezzel kapcsolatos nagyléptékű kihívások: most ünnepelhettük az új Ptk. (2013. évi V. törvény) hatálybalépésének 2. évfordulóját, emellett 2016 januárjától meg kell felelni az új biztosítási (2014. évi LXXXVIII.) törvény rendelkezéseinek is. Ezzel a biztosítási jog két legalapvetőbb jogszabálya kapott új tartalmat, amelyeknek gyakorlati alkalmazása a szakjogászok számára is kihívás, nemhogy a piaci szereplőknek, akiknek ráadásul a jog nem ismeretéből eredő közvetlen következményekkel is számolniuk kell. De nemcsak e két jogszabály változásával kellett megbirkózni a gyakorlatban, hanem például az adatvédelemmel, fogyasztóvédelemmel kapcsolatos követelmények folyamatos szigorodásával is. (Csak 2015-ben a következő rendeletek léptek életbe, amelyek újabb szabályokat fogalmaznak meg az alkuszi müködésre vonatkozóan: 14/2015. (V.13.) MNB rendelet az igazgatásszolgáltatási dijról; 44/2015. (XII.29.) MNB rendelet a felügyeleti díjról, 48/2015. (XII.8.) MNB rendelet az adatszolgáltatási kötelezettségekről; 56/2015. (XII.22.) MNB rendelet az életbiztosítási igényfelmérő tartalmi elemeiről; 58/2015. (XII.22.) MNB rendelet a törzsadat-bejelentési kötelezettségről.)

A jogszabályalkotás hatalmas tempót diktál, amellyel az alkusz kénytelen felvenni a versenyt. Hathatós külső szaksegítség nélkül kénytelen egyrészt maga követni a jogszabályi változásokat, azokat értelmezni, másrészt forrást biztosítani a megfeleléshez, és kellő időben életbe léptetni a szükséges változtatásokat a cég müködésén belül. Ez rendkívül időigényes, költséges, és az alkuszok még így is sokszor csak bizakodhatnak benne, hogy valóban kellö körültekintéssel jártak-e el.

A Független Biztosítási Alkuszok Magyarországi Szövetsége több oldalról igyekszik levenni 
az ezzel kapcsolatos munka nagy részét tagjai válláról. A - sokszor nem túl látványos, ám annál nagyobb jelentőségü - érdekképviseleti munkája során részt vesz a jogszabálytervezetekkel kapcsolatos elökészületekben, egyeztetésekben, véglegesítésben, a publikált joganyagok utánkövetésének kialakításában. Értelmezési kérdéseket vet fel, és javaslataival felhívja a figyelmet a hiányosságokra vagy a gyakorlatnak ellentmondó, illetve az annak során csak nagy nehézségek árán megvalósítható jogalkotói kezdeményezésekre.

A jogszabályi változásokkal kapcsolatosan ezután részletesen tájékoztatja a tagságot, ami nem merül ki a figyelemfelhívásban, hanem szakmai anyagokkal és előadásokkal segíti a megértést, megfelelést, valamint a gyakorlati alkalmazást.

E munkájának hatékonyságát és szakmaiságát két módon biztosítja a szövetség. Egyrészt önálló külső szakértőket vesz igénybe az egyes témákhoz igazodva. Biztosítási szakjogász segíti az érdekvédelmi tevékenységet, a módosított törvények (pl. Ptk., Bit.) kapcsán elemzést készít a változásokról, egy-egy értelmezési kérdést felvetö téma kapcsán - mint például az ügyfélpénzek kezelése - szakmai anyagot állít össze a tagság támogatására. Emellett konzultatív jelleggel, a Szövetség felkérésére részt vesz az új értékesítési irányelv implementációt előkészítő, négyoldalú (NGM-MNB-MABISZ-FBAMSZ) rendszeres informális szakmai egyeztetéseken. Fogyasztóvédelmi szakértő dolgozik azon, hogy naprakész tájékoztatást kapjanak a tagok a jogszabályi változásokról, kiemelve ezen a területen a panaszkezelést. Adószakértő segíti a Szövetség munkáját eseti jelleggel, ha adózási vagy számviteli kérdés merül fel, mint például az alvállalkozói költség elszámolásának lehetősége az iparűzési adózás rendjében.

Másrészt - a külső szakértők bevonásán túl - a Szövetség szekciókat hozott létre annak érdekében, hogy a tagság meghatározott speciális területeken csoportokban dolgozzon, koncentrálva az oda tartozó jogszabályokra, gyakorlati problémákra, jövőbeni fejlődési lehetőségekre.

\section{Az alkusz köteles megfelelni a pénzügyi felügyeletnek (MNB)}

A formálisan kötelező jogszabályi kereteken túlmenően az alkusz köteles megfelelni ellenőrző hatóságának, a Magyar Nemzeti Banknak is. Jogszabályalkotói minőségén és a gyakorlatot formáló ajánláskibocsátási jogkörén túl szót kell ejtenünk arról, hogy az alkuszi piacon az elmúlt időszakban erőteljesen megnőtt a felügyeleti prudenciális és fogyasztóvédelmi vizsgálatok száma, és a bírságok sem maradtak el.

Kiemelt vizsgálati területnek bizonyult az elmúlt évben a tájékoztatási kötelezettség maradéktalan betartása, az alkuszi nyilvántartás, az összeférhetetlenségek kiszűrése, a regisztráció nélküli közvetítés visszaszorítása és a biztosítási termékek bemutatását, összehasonlítását szolgáló és a biztosításközvetítés során használt elektronikus felületekről szóló 5/2015. (V. 05.) számú MNB ajánlásnak (azaz az „Online ajánlásnak”) való megfelelés. Helyszíni vizsgálatokra, próbavásárlásokra került sor. Kezdetben ez - mondhatni - váratlanul érte az alkuszokat, mára azonban a hétköznapi működés részévé vált olyan értelemben, hogy a brókerek számítanak arra, hogy vizsgálatot kaphatnak, így ezzel együtt folyamatosan növekszik az igény arra, hogy megfelelő tájékoztatásban részesüljenek arról, hogyan felelhetnek meg a felügyeleti követel- ményeknek, illetve hogy milyen körben végez vizsgálatot a hatóság.

\section{Megnőtt a felügyeleti vizsgálatok száma.}

A FBAMSZ a fentiekben részletezett szakértői segítségen kívül úgy segíti tagjait, hogy fórumot biztosít zárt online rendszerében és rendezvényein a tapasztalatcserére, kérdésfelvetésre, valamint a témában külön előadást is szervezett annak érdekében, hogy a tagok minél több gyakorlati információt szerezzenek a vizsgálatokról. Amennyiben pedig saját müködésükben hiányosságot fedeznek fel, azt a lehetö leghamarabb, adott esetben felügyeleti vizsgálat nélkül is korrigálhassák, ezzel növelve a tagok prudens és fogyasztóközpontú működését

Az alkuszokat az elmúlt években, különösen 2015-ben nagy kihívás elé állította a kötelező felügyeleti adatszolgáltatás, amely bővített, részletesebb adatállomány megküldését követelte meg. Sokféle értelmezési kérdés merült fel a kért adatokkal kapcsolatban, és nehézséget okozott, hogy csak utólag derült ki, milyen adatokat és milyen formában kellett volna gyüijteni az elöző év folyamán. Ezt a kérdést a FBAMSZ-on belül az IT szekció vette kézbe, amely 24 biztosítót keresett meg az adatszolgáltatással kapcsolatban annak érdekében, hogy a tagok használható formában kapjanak tájékoztatást a felügyeletet természetes módon érdeklő adatokról. A szekció emellett segítséget nyújtott az értelmezésben és kitöltésben, külön rendezvényeken tájékoztatta a tagságot a fejleményekröl, és válaszolt a felmerült kérdésekre, illetve online platformon keresztül biztosította az információcserét.

Az MNB Online Ajánlásának kidolgozásában is eredményesen részt vett az IT és az Online szekció azzal a céllal, hogy az eredetileg kibocsátásra szánt dokumentumot a gyakorlathoz igazítsák, és kellőképpen finomítsák. Ezt szintén a tagság felkészítése követte előadás és szakmai segédlet formájában.

Az új Bit. a 2015. év végén felvetette a szakmai felelősségbiztosítás utófedezetének kérdését. A szakmai szempontból - fóleg az állományátruházás szempontjából - támogatott rendelkezés gyakorlati megvalósítása kapcsán a biztosítók és az alkuszok részéröl is felmerült az igény, hogy a jogalkotó szabja meg, milyen, a gyakorlat szempontjából „elégséges” hosszúságú időbeli hatályt tart elfogadhatónak, hiszen a biztosító számára elengedhetetlen, hogy kalkulálni tudja a vállalt kockázatot, az alkuszok pedig tartanak a fedezetbővítéssel járó díjkülönbözettől. Közös fellépéssel sikerült elérni, hogy a 44/2015. (III.12.) Korm. rendelet 2016. január 2-i hatálybalépésekor már fennálló felelősségbiztosítási szerződések esetén az új szabályokat legkésőbb egy éven belül kelljen alkalmazni, és ígéret született az utófedezet időbeli hatályának pontosítására, amellyel kapcsolatban a Szövetség további érdekvédelmi konzultációt folytat.

\section{Az alkusz köteles megfelelni a biztosítók elvárásainak}

Még tovább vizsgálva azt a kérdést, hogyan biztosithatja a minőségi szolgáltatást egy független alkusz, természetszerüleg jutunk el oda, hogy köteles jó kapcsolatot ápolni, együttmüködni biztosító partnereivel, és megfelelni az általuk támasztott követelményeknek is. Túl azon, hogy 
egy minőségi szolgáltatást nyújtó alkusz köteles az értékesített termékeket részleteiben ismerni, érteni és az ajánlásuk/értékesítésük során - az ügyfél tájékoztatására kiemelt hangsúlyt fektetve - a szükségleteknek megfelelő optimális megoldást kínálni, a biztosítókkal való együttmüködés ennél jóval tovább megy.

Elsőként azt érdemes vizsgálni, hogy vajon képes-e saját érdekeit érvényesíteni egy kisebb alkusz a méreténél és piaci pozíciójánál fogva sokkal erősebb társasággal szemben, amikor együttműködésre lép egy biztosítótársasággal, és megállapodást kötnek. Képes-e a - sok esetben rosszhiszemü partnerekre kihegyezett - sztenderd együttműködési megállapodások keretein változtatni, ha egyes pontjaival nem ért egyet, nem felel meg a müködésének, vagy a jogok és kötelezettségek szempontjából aránytalannak találja, esetleg hiányol bizonyos rendelkezéseket? A gyakorlat azt mutatja, hogy az esetek többségében nem. A szakmai szövetség feladata ebben a körben a teljes tagság érdekeinek képviselete, ideértve a legkisebbeket is. A FBAMSZ külön szekciót hozott létre a kétoldalú kapcsolatok ápolására, amelynek kiemelt feladata előzetes egyeztetéseket folytatni a biztosítókáltal kibocsátott új együttműködési megállapodásokkal kapcsolatban. Ennek célja, hogy mindkét fél számára elfogadható szerződéstervezetek kerüljenek a tagsághoz, és a szerződésekkel kapcsolatos kifogásokat lehetőség szerint egységesen lehessen kezelni, közös nevezőt keresve.

A mindennapi munka során további problémák is felmerülnek, amelyek megnehezítik a gyors és precíz alkuszi munkát. A Szövetség IT szekciója elhivatottan küzd az állománylisták és jutalékjegyzékek sztenderdizálásáért, a korszerű webszerver-kapcsolat kiépítéséert az állományok lekérdezésére, mivel többletmunkát és többletköltséget eredményez, ha amennyi biztositó működik a piacon, annyi formában biztosít hozzáférést az ügyfél vagy az alkusz adataihoz. A gépjármü szekció pedig szeretné elérni, hogy a Központi kártörténeti nyilvántartót megnyissák az ügyfelek számára, tekintettel arra, hogy az ügyfelek nincsenek tisztában a róluk nyilvántartott adatokkal, ami nagymértékben meghatározza a kötelező felelősségbiztosítási szerződésük díát. További törekvése a szekciónak, hogy úiraszabályozzák a kgfb-flottaszerződéseket, és bevezessék a direkt kárrendezést. Emellett jelenleg is folyik a munka a MABISZ-szal és MNB-vel az elektronikus alkuszi megbízás gyakorlatban is megfelelő módon történő alkalmazhatóságával kapcsolatban.

\section{【Évi legalább 15 óra továbbképzésen kell részt venni.}

A gépjármű-biztositásoknál maradva ugyancsaknagykihívást jelent ésjelentett azalkuszokszámára az Astra Biztosító felszámolása és a vonatkozó rendezetlen, illetve bonyolult, a román jogrendszerre is kiterjedő jogi környezet, a megfelelő tájékoztatás hiánya; valamint a KÖBE (Közlekedési Biztosító Egyesület) tevékenységének részleges, időszakos felfüggesztése. A folyamatos, naprakész tájékoztatáson túl a Szövetség hívta fel az MNB figyelmét az Astra Biztosító felszámolása okán szükségessé vált törvénymódositás pontatlanságára: amennyiben az ügyfél nem mondja fel szerződését, illetve nem köt új szerződést az évfordulóval, akkor nem szünik meg a szerződése, ami további számos problémát okozhat, és amelyre így a jogalkotó, pontosabban a felügyelet rövid időn belül tudott reagálni. Emellett folyamatosan kezelte a biztosító szerződési nyilvántartásából, adatközlési hiányosságaiból eredő problémákat, mint például a bónuszok átvezetése, kárkifizetés, kárbejelentés, dijvisszatérités.

\section{Az alkusz köteles naprakésznek lenn}

Végezetül, de nem utolsósorban, ha az alkusz megfelel a müködésével kapcsolatos alapkövetelményeknek, ügyfélközpontú tevékenységet folytat, megfelel a jogszabályoknak, a felügyeleti követelményeknek, és zökkenőmentes, gyümölcsöző kapcsolatot ápol biztosító partnereivel, még mindig hátravan az az elvárás, hogy folyamatosan naprakész tudással, szakismerettel rendelkezzen, és ezt minden egyes alkalmazottja esetében vizsgálja, illetve biztosítsa.

A biztositók folyamatos termékfejlesztéseinek sodrásában, a folyamatosan bővülő termékkínálat, a jelenleg elvárt termékszintű ismeretek és a cégen belüli fluktuáció mellett ez közel sem egyszerű feladat, különösen a kisebb méretű alkuszcégek esetében, amelyeknek nincs a szervezeten belül kialakított oktatási, ismeretellenőrzési rendszere. Ráadásul az úi, most már nem biztositásközvetítési, hanem a bővített (scope) hatály miatt biztositási értékesítési irányelvvel is szigorodni fognak a képzési követelmények, amikor minimum elvárásként rögzítik majd, hogyévi legalább 15 óra továbbképzésen kell részt venni. Ebben a körben a Szövetség oktatási szekciójának feladata, hogy szakmai képzéseket, továbbképzéseket szervezzen, az IDD által meghatározott képzésekkel kapcsolatos lobbitevékenységet végezzen, és modern, webináriumi keretek között még szélesebb körben biztosítsa tagjai számára az oktatáshoz való hozzáférést. A szekció jövőbeni célja az, hogy a Szövetség által szervezett képzések beleszámítsanak a jogszabályi megfelelőséget biztosító kreditpontokba.

Mint a fenti áttekintés bemutatta, egy minőségi alkuszcég számtalan szabálynak, kötelezettségnek és elvárásnak tesz eleget egyidejüleg. Amikor a megbízó egy alkuszcéggel partneri kapcsolatba lép, ritkán képes felmérni, hogy a megbízást kapó bróker vajon mennyire teljesíti a minőségi működés követelményeit.

A FBAMSZ mint érdekvédelmi szövetség a törvények, rendeletek, ajánlások, szabályozások kialakítása során állhatatosan és minőségi módon képviseli tagsága érdekeit. Ugyanakkor tagcégeit közvetlenül is segíti abban, hogy működésük minden - így prudenciális és fogyasztóvédelmi szempontból is - megfeleljen az elvárásoknak.

\section{FORRÁSOK}

Az Európai Parlament és a Tanács (EU) 2016/97 irányelve (2016. január 20) a biztositásie értékesitésről (átdolgozás) - IDD" 2013. évi V. törvény. a Polgári Törvénykönyvröl 2014. évi LXXXVIII. törvény a biztositási tevékenységről 14/2015. (V.13.) MNB rendelet az igazgatásszolgáltatási dijro 44/2015. (XI.29.) MNB rendelet a felügyeleti dijiról

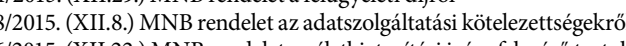

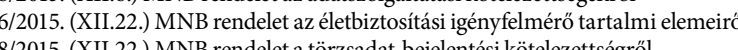
44/2015. (III.12.) Korm. rendelet a többes ügynöki és az alkuszi felelolosségbiztositási szerződés minimális tartalmi követelményeiró $<$ http://www.pwc.com/gx/en/insurance/publications/assets/reaping-dividends-cyber-resilience.pdf> [Letöltve: 2015.10.30]. 5/2015. (V. 05.) számú MNB ajánlás a biztositási termékek bemutatááat, összehasonlitását szolgáló és a biztositásközvetités során hasz-

A Független Magyar Biżositási Alkuszok Üzleti Etikai Kódexe 